\title{
Actinomyces bovis
}

National Cancer Institute

\section{Source}

National Cancer Institute. Actinomyces bovis. NCI Thesaurus. Code C86107.

A species of anaerobic, Gram positive, rod shaped bacteria assigned to the phylum

Actinobacteria. A. bovis is an opportunistic pathogen in the oral and nasopharyngeal

mucous membranes and is the causative agent of actinomycosis in cattle. 